Saudi Journal of Business and Management Studies Abbreviated Key Title: Saudi J Bus Manag Stud ISSN 2415-6663 (Print) |ISSN 2415-6671 (Online) Scholars Middle East Publishers, Dubai, United Arab Emirates Journal homepage: http://scholarsmepub.com/sjbms/

Original Research Article

\title{
Analysis of Influence of Motivation, Discipline, Training and Leadership on Performance of Employees Marketing Funding Bank Danamon Jakarta
}

\author{
Lisnatiawati Saragih* \\ Lecturer at Mercu Buana University Jakarta
}

DOI: $10.36348 /$ sjbms.2019.v04i11.001

| Received: 19.10.2019 | Accepted: 26.10.2019 | Published: 11.11 .2019

*Corresponding author: Lisnatiawati Saragih

Abstract

This study aims to look at employee performance, especially the Marketing Funding section at PT. Bank Danamon Indonesia Jakarta branch. The planned activities (1) Formulate problems. (2) Develop a frame of mind. (3) Arrange hypotaesis. (4) Perform data experiment / processing. (5) Drawing conclusions. (6) Reporting and scientific publications in ISSN journals.

Keywords: Employee Performance.

Copyright @ 2019: This is an open-access article distributed under the terms of the Creative Commons Attribution license which permits unrestricted use, distribution, and reproduction in any medium for non-commercial use (NonCommercial, or CC-BY-NC) provided the original author and source are credited.

\section{BACKGROUND}

Human resource management is a collection or series of decision makers regarding employment relations that affect the effectiveness of employees in a company organization. To increase work productivity in daily tasks as a workforce or as a controller of all organizational activities of a company, it can be done in many ways including guidance by providing effective leadership and providing continuous training and providing examples of high discipline by providing motivation well. Motivation, Discipline, Training and Leadership have a role in improving Employee Performance, because without all of this it is clear the meaning of the goals of the organization in a company becomes weak. These conditions can lead to situations where individuals only work to achieve personal goals, while the overall goals of the organization become inefficient in achieving the goals set. Therefore Motivation, Discipline, Training and Leadership are needed in an organization to achieve success.

In the competition in the banking world it is not an easy thing, especially competition in the provision of services through superior products owned by each bank itself. Each bank will very actively provide convenience in doing transactions either through the internet site, 24-hour non-stop service or through friendly and touching customer service, but also crisis factors related to the success of an organization by measuring how well its employees are in work, and enthusiastic in serving customers by using existing information and facilities so as to ensure the fulfillment of the fulfillment of the standardization of duties and responsibilities of a Marketing Funding at PT. Bank Danamon Indonesia, especially in the Jakarta Branch.

\section{RESEARCH PURPOSES}

To find out the significant influence between:

- Motivation of Employee Performance from Marketing Funding at PT. Bank Danamon Indonesia Jakarta Branch.

- Discipline on Employee Performance from Marketing Funding at PT. Bank Danamon Indonesia Jakarta Branch. 
- Training on Employee Performance from Marketing Funding at PT. Bank Danamon Indonesia Jakarta Branch.

- Leadership on Employee Performance from Marketing Funding at PT. Bank Danamon Indonesia Jakarta Branch.

- Motivation, discipline and training and leadership together to Employee Performance from Marketing Funding at PT. Bank Danamon Indonesia Jakarta Branch.

\section{LITERATURE REVIEW \\ Motivation}

The definition of motivation stated by Raden Lestari Garnasih [1] is psychological forces that determine the direction of an individual's behavior in an organization, the level of effort and perseverance of a person.

\section{Discipline}

Discipline is the awareness and willingness of a person to obey all company regulations and social norms that apply [2].

Work discipline can be interpreted as the implementation of management to reinforce organizational guidelines [3]. There are two forms of work discipline, namely [4]: Preventive Discipline and Corrective Discipline.

\section{Training}

According to Mathis and Jackson in Priansa [5], types of training:

\begin{tabular}{|c|l|l|}
\hline No & \multicolumn{1}{|c|}{ Alasan } & \multicolumn{1}{c|}{ Penjelasan } \\
\hline 1. & Routine Training & $\begin{array}{l}\text { The required and routine training is carried out to } \\
\text { fulfill various legal requirements that are } \\
\text { required and act as training for all employees } \\
\text { (new employee orientation) }\end{array}$ \\
\hline 2. & Technical Training & $\begin{array}{l}\text { Job / technical training allows employees to do } \\
\text { their jobs, tasks and responsibilities well, for } \\
\text { example: knowledge of products, technical } \\
\text { processes and procedures, and customer } \\
\text { relations.. }\end{array}$ \\
\hline 3. & $\begin{array}{l}\text { Interpersonal Training } \\
\text { and Problem Solving }\end{array}$ & $\begin{array}{l}\text { Intended to address operational and interpersonal } \\
\text { problems and improve relations in organizational } \\
\text { work, for example: interpersonal communication, } \\
\text { managerial or supervisory skills, conflict } \\
\text { resolution. }\end{array}$ \\
\hline 4. & $\begin{array}{l}\text { Innovative } \\
\text { Development Training }\end{array}$ & $\begin{array}{l}\text { Providing a long-term focus on improving } \\
\text { individual and organizational capabilities for the } \\
\text { future, for example business practices, executive } \\
\text { development, and organizational change. }\end{array}$ \\
\hline
\end{tabular}

\section{Leadership}

According to Robbins [6] leadership is the ability to influence a group towards achieving a vision or goal set. And according to Sutikno [7] "Leadership is a process that influences group activities that are set to achieve common goals"

\section{The performance}

Performance in English is called job performance or actual performance or level of performance, which is the level of employee success in completing work. Performance is an embodiment of ability in the form of real work. Performance is the result of work achieved by employees in carrying out tasks and jobs in the organization [5].

\section{RESEARCH METHODS}

\section{Design and Research Stages}

The research design used by researchers in this study is causal research. According to Sugiyono [8] causal is a causal relationship where the independent variable influences the dependent variable. This study aims to test the hypothesis about the effect of one or several variables on other variables with a statistical test. Where this study aims to determine the effect of Motivation (X1), Discipline (X2), Training (X3) and Leadership (X4) on Employee Performance (Y).

The population of this study is the real recapitulation of Bank Danamon Indonesia's Marketing Funding as of March 2018 totaling 185 people.

\section{Data Collection Techniques}

Samples are part of the number and characteristics possessed by the population and sampling is done by simple random sampling technique that is sampling of members of the population randomly and proportionally without regard to strata in the population.

According to Sugiyono [8] the sample is part of the number and characteristics possessed by the population. Determination of the amount of sampling is done by the Slovin formula: 


$$
\mathrm{n}=\frac{\mathrm{N}}{1+\mathrm{N}(\mathrm{e})^{2}}
$$

Dimana:

$$
\begin{aligned}
& \mathrm{n}=\text { sampel } \\
& \mathrm{N}=\text { population } \\
& \mathrm{E}=\% \text { Error. } \\
& \mathrm{n}=\frac{185}{1+185(0,1)^{2}} \\
& \mathrm{n}=65 \text { sampel }
\end{aligned}
$$

Data collection techniques that will be used in this study are as follows

- Field research by conducting research directly on the object of research to obtain data, information and other information needed.

- Questionnaire creation for respondents: data collection through a list of questions / statements with answers provided to be chosen (closed questionnaire) submitted to parties directly related to the problem to be examined

- Literature study: collecting data by theoretically examining the library to obtain theories related to and supporting the problem to be examined.

\section{Variable Definition and Measurement}

This study involved five variables, namely $\mathrm{Y}$ variable (employee performance), X1 variable (motivation), X2 variable (discipline), X3 variable (training) and X4 variable (leadership).

So that the research concept can be investigated empirically, the concept must be operationalized by transforming it into a variable or something that has a variable value.

In this research, to prove the hypothesis that has been made two analyzes are carried out using simple linear regression and multiple linear regression

All data collected is grouped, tabulated and made calculations. Weighting using the Linkert scale on respondents' answers on each of the variables studied Teknik dan Metode Analisa Data

\section{RESEARCH RESULTS AND DISCUSSION}

The objects of research are Motivation, Discipline, Training and Marketing Funding Leadership of Bank Danamon Indonesia, amounting to 65 people with demographics as shown in the following table:

\section{Descriptive Respondents based on Gender}

For the Gender most respondents are 39 women out of 65 people, this is understandable because in the banking world women are more able to touch customers in placing third party funds

\begin{tabular}{|c|l|r|r|r|r|}
\hline \multicolumn{7}{|c|}{ Gender of Respondents } \\
\hline \multirow{2}{|c|}{} & Frequency & Percent & $\begin{array}{c}\text { Valid } \\
\text { Percent }\end{array}$ & $\begin{array}{c}\text { Cumulative } \\
\text { Percent }\end{array}$ \\
\hline \multirow{3}{*}{ Valid } & Men & 26 & 40.0 & 40.0 & 40.0 \\
\cline { 2 - 6 } & Woman & 39 & 60.0 & 60.0 & 100.0 \\
\cline { 2 - 6 } & Total & 65 & 100.0 & 100.0 & \\
\hline
\end{tabular}

\section{Descriptive Respondents based on Final Education}

Descriptive respondents mostly based on Final Education (78\% as many as 51 people out of 65 people) are Bachelor (Strata 1), this is one of the requirements when recruiting

\begin{tabular}{|r|l|r|r|r|r|}
\hline \multicolumn{7}{|c|}{ Education of Respondents } \\
\hline \multirow{2}{|c|}{} & Frequency & Percent & $\begin{array}{c}\text { Valid } \\
\text { Percent }\end{array}$ & $\begin{array}{c}\text { Cumulative } \\
\text { Percent }\end{array}$ \\
\hline Valid & D3 & 9 & 13.8 & 13.8 & 13.8 \\
\hline & Lainnya & 5 & 7.7 & 7.7 & 21.5 \\
\hline & S1 & 51 & 78.5 & 78.5 & 100.0 \\
\cline { 2 - 6 } & Total & 65 & 100.0 & 100.0 & \\
\hline
\end{tabular}

\section{Descriptive Respondents based on Age}

For the age of most respondents as marketing funding ranged in age from 20-29 years with presentations of $38.5 \%$ (as many as 25 people) and followed by ages around 30-39 years with presentations of $35.4 \%$ (as many as 23 people) of total respondents totaling 65 person. Age range is the productive age for a marketing funding. 


\begin{tabular}{|c|c|r|r|r|r|}
\hline \multicolumn{5}{|c|}{ age of respondent } \\
\hline \multirow{2}{|c|}{} & Frequency & Percent & $\begin{array}{c}\text { Valid } \\
\text { Percent }\end{array}$ & $\begin{array}{c}\text { Cumulative } \\
\text { Percent }\end{array}$ \\
\hline \multirow{3}{*}{ Valid } & $>40$ th & 17 & 26.2 & 26.2 & 26.2 \\
\cline { 2 - 6 } & $20-29$ th & 25 & 38.5 & 38.5 & 64.6 \\
\cline { 2 - 6 } & $30-39$ th & 23 & 35.4 & 35.4 & 100.0 \\
\cline { 2 - 6 } & Total & 65 & 100.0 & 100.0 & \\
\hline
\end{tabular}

\section{Descriptive Respondents based on length of work}

If we look at the respondent's data, it is seen that the length of time most respondents work is over 5 years (there are $41.5 \%$ ) as many as 27 people from 65 respondents, it can be concluded that they feel quite comfortable working at Bank Danamon as marketing funding.

\begin{tabular}{|c|c|c|c|c|c|}
\hline \multicolumn{6}{|c|}{ Years of Respondents' Work } \\
\hline & & Frequency & Percent & $\begin{array}{l}\text { Valid } \\
\text { Percent }\end{array}$ & $\begin{array}{l}\text { Cumulative } \\
\text { Percent }\end{array}$ \\
\hline \multirow{5}{*}{ Valid } & $<2$ Thn & 12 & 18.5 & 18.5 & 18.5 \\
\hline & $>5 \mathrm{Thn}$ & 27 & 41.5 & 41.5 & 60.0 \\
\hline & $2-5 \mathrm{Th}$ & 25 & 38.5 & 38.5 & 98.5 \\
\hline & Lainnya & 1 & 1.5 & 1.5 & 100.0 \\
\hline & Total & 65 & 100.0 & 100.0 & \\
\hline
\end{tabular}

\begin{tabular}{|c|c|c|c|c|c|c|}
\hline \multicolumn{7}{|c|}{ Correlations } \\
\hline & & Motivasi & Disiplin & Pelatihan & Kepemimpinan & Kinerja \\
\hline \multirow[t]{3}{*}{ Motivasi } & Pearson Correlation & 1 & $.908^{* * *}$ & $.903^{* *}$ & $.567^{* *}$ & $.849^{* * *}$ \\
\hline & Sig. (2-tailed) & & .000 & .000 & .000 & .000 \\
\hline & $\mathrm{N}$ & 64 & 64 & 64 & 64 & 64 \\
\hline \multirow[t]{3}{*}{ Disiplin } & Pearson Correlation & $.908^{* * *}$ & 1 & $.912^{* * *}$ & $.574^{* *}$ & $.886^{* * *}$ \\
\hline & Sig. (2-tailed) & .000 & & .000 & .000 & .000 \\
\hline & $\mathrm{N}$ & 64 & 65 & 65 & 65 & 65 \\
\hline \multirow[t]{3}{*}{ Pelatihan } & Pearson Correlation & $.903^{* * *}$ & $.912^{* * *}$ & 1 & $.588^{* * *}$ & $.887^{* * *}$ \\
\hline & Sig. (2-tailed) & .000 & .000 & & .000 & .000 \\
\hline & $\mathrm{N}$ & 64 & 65 & 65 & 65 & 65 \\
\hline \multirow{3}{*}{$\begin{array}{l}\text { Kepemimpina } \\
\mathrm{n}\end{array}$} & Pearson Correlation & $.567^{* *}$ & $.574^{\text {*** }}$ & $.588^{* * *}$ & 1 & $.696^{\text {*** }}$ \\
\hline & Sig. (2-tailed) & .000 & .000 & .000 & & .000 \\
\hline & $\mathrm{N}$ & 64 & 65 & 65 & 65 & 65 \\
\hline \multirow[t]{3}{*}{ Kinerja } & Pearson Correlation & $.849^{* *}$ & $.886^{* * *}$ & $.887^{* * *}$ & $.696^{* * *}$ & 1 \\
\hline & Sig. (2-tailed) & .000 & .000 & .000 & .000 & \\
\hline & $\mathrm{N}$ & 64 & 65 & 65 & 65 & 65 \\
\hline
\end{tabular}

From the above table statement it can be concluded that each variable is valid and significant because the value of sig ( 2 tailed) is below 0.05 of the 65 respondents.

\begin{tabular}{|r|r|}
\hline \multicolumn{2}{|c|}{ Reliability Statistics } \\
\hline Cronbach's Alpha & N of Items \\
\hline .977 & 25 \\
\hline
\end{tabular}

\section{Analysis of Reliability}

Based on the test results it is known that the Cronbach alpha value is 0.977 , so this number is greater than the minimum Cronbach alpha value of 0.6. Therefore it can be concluded that the research instrument used to measure the variables of motivation, discipline, training, leadership and performance can be said to be reliable and reliable. 


\section{Uji Kualitas Data}

\section{Normality test}

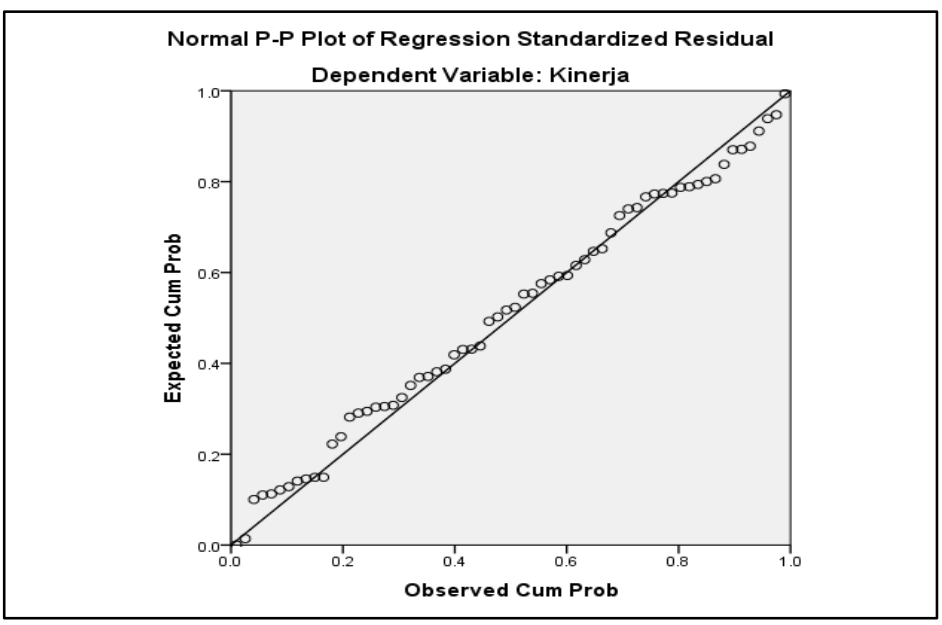

NPP of Regression Standardized Residual

\section{Correlation Coefficient}

\begin{tabular}{|l|c|c|c|c|}
\hline \multicolumn{2}{|c|}{ Model Summary } \\
\hline Model & $\mathrm{R}$ & R Square & $\begin{array}{c}\text { Adjusted R } \\
\text { Square }\end{array}$ & $\begin{array}{c}\text { Std. Error of the } \\
\text { Estimate }\end{array}$ \\
\hline 1 & $.929^{\mathrm{a}}$ & .863 & .854 & 1.89889 \\
\hline \multicolumn{2}{|r|}{ a. Predictors: (Constant), Kepemimpinan, Motivasi, Pelatihan, Disiplin } \\
\hline
\end{tabular}

Simple linear regression analysis conducted with the SPSS program can be seen that the coefficient of correlation $\mathbb{B}=0,929$ which means the strength of the relationship between leadership, motivation, training and discipline variables to positive performance and has a very high correlation.

\section{Coefficient of determination}

The coefficient of determination or $\mathrm{R}$ Square of 0.863 is the square of the correlation coefficient. This shows $86.3 \%$ of the dependent variable (Performance) is determined by factors of leadership, motivation, training and discipline while the remaining $13.7 \%$ is determined by other factors.

T test

\begin{tabular}{|c|c|c|c|c|c|c|}
\hline \multicolumn{7}{|c|}{ Coefficients $^{\mathbf{a}}$} \\
\hline \multirow{2}{*}{\multicolumn{2}{|c|}{ Model }} & \multicolumn{2}{|c|}{ Unstandardized Coefficients } & \multirow{2}{*}{$\begin{array}{c}\begin{array}{c}\text { Standardized } \\
\text { Coefficients }\end{array} \\
\text { Beta } \\
\end{array}$} & \multirow[t]{2}{*}{$\mathrm{t}$} & \multirow[t]{2}{*}{ Sig. } \\
\hline & & $\mathrm{B}$ & Std. Error & & & \\
\hline \multirow[t]{5}{*}{1} & (Constant) & -.278 & 1.112 & & -.250 & .804 \\
\hline & Motivation & .021 & .113 & .024 & .185 & .854 \\
\hline & Discipline & .323 & .109 & .398 & 2.976 & .004 \\
\hline & Training & .378 & .138 & .360 & 2.739 & .008 \\
\hline & Leadership & .340 & .083 & .246 & 4.104 & .000 \\
\hline
\end{tabular}

\section{F test or ANOVA test}

With the help of the SPSS program, a F count of 92, 976 was obtained, while the critical price of the F table with a caretaker degree 1 and the denominator of 63 at a significant level of 0.05 was 3.993. Thus if $\mathrm{F}$ arithmetic $(92,976)>\mathrm{F}$ table $(3,993)$ so clearly $\mathrm{Ho}$ is rejected and $\mathrm{Ha}$ is accepted, this shows that the regression model of leadership, motivation, training and discipline variables has a significant effect on the Performance variable. 


\begin{tabular}{|c|c|c|c|c|c|c|}
\hline \multicolumn{7}{|c|}{ ANOVA $^{\mathrm{a}}$} \\
\hline \multicolumn{2}{|c|}{ Model } & $\begin{array}{l}\text { Sum of } \\
\text { Squares }\end{array}$ & df & $\begin{array}{l}\text { Mean } \\
\text { Square }\end{array}$ & $\mathrm{F}$ & Sig. \\
\hline \multirow[t]{3}{*}{1} & Regression & 1341.008 & 4 & 335.252 & 92.976 & $.000^{\mathrm{b}}$ \\
\hline & Residual & 212.742 & 59 & 3.606 & & \\
\hline & Total & 1553.750 & 63 & & & \\
\hline \multicolumn{7}{|c|}{ a. Dependent Variable: Performance } \\
\hline
\end{tabular}

\section{CONCLUSIONS AND SUGGESTIONS Conclusion}

From the results of data analysis and hypothesis testing the following conclusions can be drawn:

- There is a significant influence between motivations on Employee Performance of Marketing Funding at PT. Bank Danamon Indonesia Jakarta Branch.

- There is a significant influence between disciplines on Employee Performance of Marketing Funding at PT. Bank Danamon Indonesia Jakarta Branch.

- There is a significant influence between training on Employee Performance of Marketing Funding at PT. Bank Danamon Indonesia Jakarta Branch.

- There is a significant influence between leadership on Employee Performance of Marketing Funding at PT. Bank Danamon Indonesia Jakarta Branch.

- There is a significant influence between motivation, discipline and training and leadership together on the Employee Performance of Marketing Funding at PT. Bank Danamon Indonesia Jakarta Branch.

\section{Suggestion}

\section{Banking services}

- More able to empower HR in the activities of achieving targets through an important role in motivation, discipline, training and leadership in marketing funding performance so that HR feels the organizational goals are part of the HR objectives in it to be more responsible in achieving those goals.

- Organizations can better understand and apply more advanced technology in the face of market competition to support the duties and responsibilities of a marketing funding.
- Achievement of maximum performance will be the basis for reference from the company's Top Management in order to create a predetermined Vision and Mission.

\section{General public}

- Knowledge of the work processes and responsibilities of a marketing funding and further analysis for the general public to be able to digest every product that will be provided by banks and apply the independent variables in this research to be applied and run on other similar companies or companies that are not the same kind.

- As a material for further agreement with a broader conceptual study, it can affect the performance of marketing funding or similar related sections.

- As input for comparative studies in research for other banking marketing.

\section{REFFERENCE}

1. Garnasih, R. L. (2017). Motivasi: Expectancy Theory dan Produktivitas Penelitian. Jurnal Inspirasi Bisnis dan Manajemen, 1(1), 53-62.

2. Hasibuan, M.S.P. (2013). Manajemen sumber daya manusia. Jakarta: Bumi Aksara.

3. Mangkunegara, A. A., Anwar Prabu.(2014). Manajemen Sumber Daya Manusia Perusahaan, Remaja Rosdakarya, Bandung.

4. Mangkunegara, A. A., Anwar, Prabu. (2013). Manajemen Sumber Daya Manusia Perusahaan, Remaja Rosdakarya, Bandung.

5. Mathis dan Jackson dalam Priansa. (2016). Jenisjenis Pelatihan

6. Robbins, S.P., dan Judge, T.A. (2015). Perilaku Organisasi. Jakarta: Salemba Empat.

7. Sutikno. (2014). Pemimpin dan Gaya Kepemimpinan.Edisi Pertama Lombok; Holistica.

8. Sugiyono. (2014). Metode Penelitian Manajemen. Bandung: CV Alfabeta. 